\title{
New insights into the early life ecology of Sardina pilchardus (Walbaum, 1792) in the northern Iberian Atlantic
}

\author{
SANDRA RAMOS ${ }^{1,2}$, PEDRO RÉ ${ }^{3}$ and ADRIANO A. BORDALO ${ }^{1,2}$ \\ ${ }^{1}$ Laboratory of Hydrobiology, Institute of Biomedical Sciences, University of Porto, Largo Professor Abel Salazar, no. 2, \\ 4099-003 Porto, Portugal. E-mail: ssramos@icbas.up.pt \\ ${ }^{2}$ Centro Interdisciplinar de Investigação Marinha e Ambiental (CIIMAR), Rua dos Bragas 289, 4050-123 Porto, Portugal. \\ ${ }_{3}^{3}$ Faculdade de Ciências da Universidade de Lisboa, Laboratório Marítimo da Guia / Centro de Oceanografia, Av. de Nossa \\ Senhora do Cabo 939, 2750-374 Cascais, Portugal.
}

SUMMARY: In the Atlantic Iberian estuaries, sardines tend to be a minor component of the ichthyoplankton assemblages, with rare occurrence largely restricted to estuarine mouths. However, this was not the case of the Lima estuary (NW Portugal), where sardines were the most abundant and frequently occurring marine taxon of the larval fish assemblages. Abundance of sardines collected during a two-year survey (2002-2004) ranged from 0.5 to 60.8 larvae/100 $\mathrm{m}^{3}$, with the majority still showing yolk and unpigmented eyes. Moreover, $80 \%$ of sardines were 8 days old or less and the total length ranged from 2 to $16 \mathrm{~mm}$. Seasonal variations of sardine occurrence in the Lima estuary correlated with temporal variations of salinity and temperature in the water column. The unusually high river-flow observed during the winter of 2002-2003, which preceded the spring-summer abundance peak, seemed to act as a signal for the estuarine recruitment that was encountered. In addition, the estuarine occurrence of sardine larvae was also correlated with the intensity of summer upwelling, which was responsible for coastal depletion of sardine larvae resulting in estuarine low catches during the summer of 2002. The Lima estuary also revealed another peculiarity related to the lack of temporal synchrony between coastal spawning activity and occurrence of larvae within the estuary. The abundance peaks of newly-hatched larvae (autumn 2002 and spring-summer 2003) did not coincide with the winter-spring spawning pattern described earlier for the northern Iberian coast. Modifications of the spawning strategy of the northern Iberian sardine stock are discussed based on these new insights into the early life of S. pilchardus.

Keywords: Sardina pilchardus, larval stages, spawning strategy, environmental forcing, upwelling, Lima River estuary.

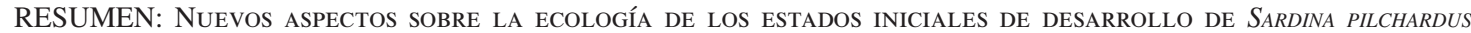
(WALBAUM, 1792) EN El NORTE DEL ATLÁNTICO IBÉRICO. - Las sardinas tienden a ser un componente menor del ictioplancton de los estuarios atlánticos ibéricos. Su aparición es rara y restringida, en gran parte, a las desembocaduras de los ríos. Sin embargo, éste no fue el caso del estuario del río Lima (NW Portugal), donde las sardinas fueron la especie marina más abundante del ictioplanton estuarino. Las sardinas fueron recolectadas durante un período de dos años (2002-2004), y su abundancia varió entre $0.5-60.8$ larvas $/ 100 \mathrm{~m}^{3}$. La mayoría de dichas larvas todavía presentaban saco vitelino y ojos no pigmentados. Por otra parte, el $80 \%$ de las sardinas tenían 1 semana o menos de vida y su longitud total varió entre 2 y $16 \mathrm{~mm}$. Las variaciones estacionales en la aparición de larvas de sardina en el estuario del río Lima se correlacionaron con fluctuaciones temporales de salinidad y de temperatura de la columna de agua. Los elevados caudales del río observados durante el invierno 2002-2003, que precedieron el pico de abundancia del primavera-verano, parecieron actuar como señal para el reclutamiento al estuario. Además, la aparición en el estuario de larvas de sardina también fue controlada por la intensidad del afloramiento de verano, responsable de la disminución de abundancia de larvas de sardina en la costa, lo que dio lugar a bajas capturas en el estuario durante el verano 2002. Además la inusual aparición de larvas de sardina, dentro del estuario del río Lima reveló otra particularidad relacionada con la carencia de sincronía temporal entre la actividad de freza y la aparición de larvas dentro del estuario. Los picos de abundancia de larvas recien eclosionadas (otoño 2002 y período de primavera-verano de 2003) no coincidieron con la época de puesta invernal previamente descrita para la costa norte de la península ibérica. Estos nuevos datos sobre la ecología de los estados iniciales de desarrollo de la sardina se discuten a la luz de las modificaciones de la estrategia reproductiva del stock de sardinas del norte del Atlantico ibérico.

Palabras clave: Sardina pilchardus, estados larvarios, estrategia reproductiva, control ambiental, afloramiento, estuario del río Lima. 


\section{INTRODUCTION}

The European sardine (Sardina pilchardus Walbaum, 1792) is a planktivorous species with a wide distribution in both NE Atlantic waters (from Mauritania to the North Sea) and the Mediterranean Sea (Porteiro et al., 1996). In Atlantic waters, it is a target species for the Moroccan, Spanish and Portuguese fishing fleets (Pestana, 1989). In Portugal, this fishery represents more than $40 \%$ of the total annual national landings, highlighting its socioeconomic importance. However, in the past few decades, sardine landings off the western Iberian Peninsula have been decreasing, concomitantly with a decline in overall small pelagic fish productivity (Guisande et al., 2001; Santos et al., 2001; Borges et al., 2003). It has been reported that the decreasing trends of sardine observed in NW Iberia are associated with variations in prevailing winds and upwelling patterns (Santos et al., 2001; Borges et al., 2003). In the case of upwelling, the main effect is the transport of eggs and larvae offshore by northern winds (Guisande et al., 2001). Thus, strong upwelling events during the recruitment season decrease the probability of survival of sardine larvae as they are dispersed to outer shelf and oceanic zones (Bode et al., 2007).

The sardine is a batch spawner, since females spawn partially on several occasions within a single season (Andreu and Pinto, 1957; Blaxter and Hunter, 1982; Quintanilla and Pérez, 2000). On the Iberian Atlantic coast, two main spawning areas have been identified, one along the Portuguese coast (Cunha and Figueiredo, 1988), and one in the Cantabrian Sea (García et al., 1998). In Portugal spawning occurs primarily off the northern part of the continental shelf in November-April, with two main peaks of intensity (November to January and April/May) (Ré, 1986; Figueiredo and Santos, 1989; Pestana, 1989; Ré et al., 1990; Borges et al., 2003). In contrast, in the Cantabrian Sea, further north, spawning starts earlier in October and extends until July (Lago de Lanzós et al., 1988; Solá et al., 1992). In European Atlantic waters, spawning is restricted to the shelf when temperatures are within the $12-17^{\circ} \mathrm{C}$ range (Bernal et al., 2007). The spring peak in spawning activity is temporally broader off northern Spain, as is the winter peak off the western and southern Iberian Peninsula (Stratoudakis et al., 2007).

Estuaries worldwide are recognised as important nursery habitats for early life history stages of fishes (Powles et al., 1984; Whitfield, 1999; Blaber, 2000; Elliott and Hemingway, 2002). The early life stages of European sardines are thought to be limited to coastal areas (Ré et al., 1990; John et al., 1996; Chícharo et al., 1998; Olivar et al., 2003; Coombs et al., 2004; Santos et al., 2004), because they seem to avoid the high turbidity and low salinity typical of North Atlantic estuaries. Therefore, the presence of larvae of S. pilchardus in Atlantic Iberian estuaries has been considered rare and restricted to the adjacent coastal zone off the estuaries (Ré, 1999). This was not the case of the Lima estuary, where sardines were the most abundant and frequently occurring marine taxon in the larval fish assemblages (Ramos et al., 2006a). Due to the high economic importance of sardines in European fisheries, the presence of sardine larval stages in the Lima estuary is of interest. This works reports on the unusual abundance of sardine early life within an estuarine system and investigates the association of environmental factors with the spatial and temporal patterns of larval sardine age groups in the Lima estuary.

\section{MATERIALS AND METHODS}

\section{Study area}

The Lima River is an international water body draining into the Atlantic Ocean at $41^{\circ} 40^{\prime} \mathrm{N}$ and $8^{\circ} 50^{\prime} \mathrm{W}$ near Viana do Castelo (Fig. 1). Its watershed covers $2446 \mathrm{~km}^{2}$. The river mouth is partially obstructed by a 2-km-long jetty, deflecting the river flow to the south. The Lima estuary has a semidiurnal, mesotidal regime. Salt intrusion extends to 12 $\mathrm{km}$ upstream, with an average flushing rate of 0.5 $\mathrm{m} \mathrm{s}^{-1}$ and a residence time of 9 days (Ramos et al., 2006 a). The study area, located in the lower $7 \mathrm{~km}$ stretch of the estuary, includes an initial dredged and narrow navigation channel and an upstream shallow and wide saltmarsh zone, mainly colonised by Juncus spp., with a large longitudinal sandy island (Cavalar Island). The first four stations (1-4) were located within the navigation channel, while the remaining stations (5-11) were distributed within the shallow saltmarsh zone. According to the morphology of the estuary and the salt intrusion, the initial polyhaline dredged navigation channel was considered as lower estuary, while the brackish shallow and wider saltmarsh area was designated as middle estuary (Fig. 1). 


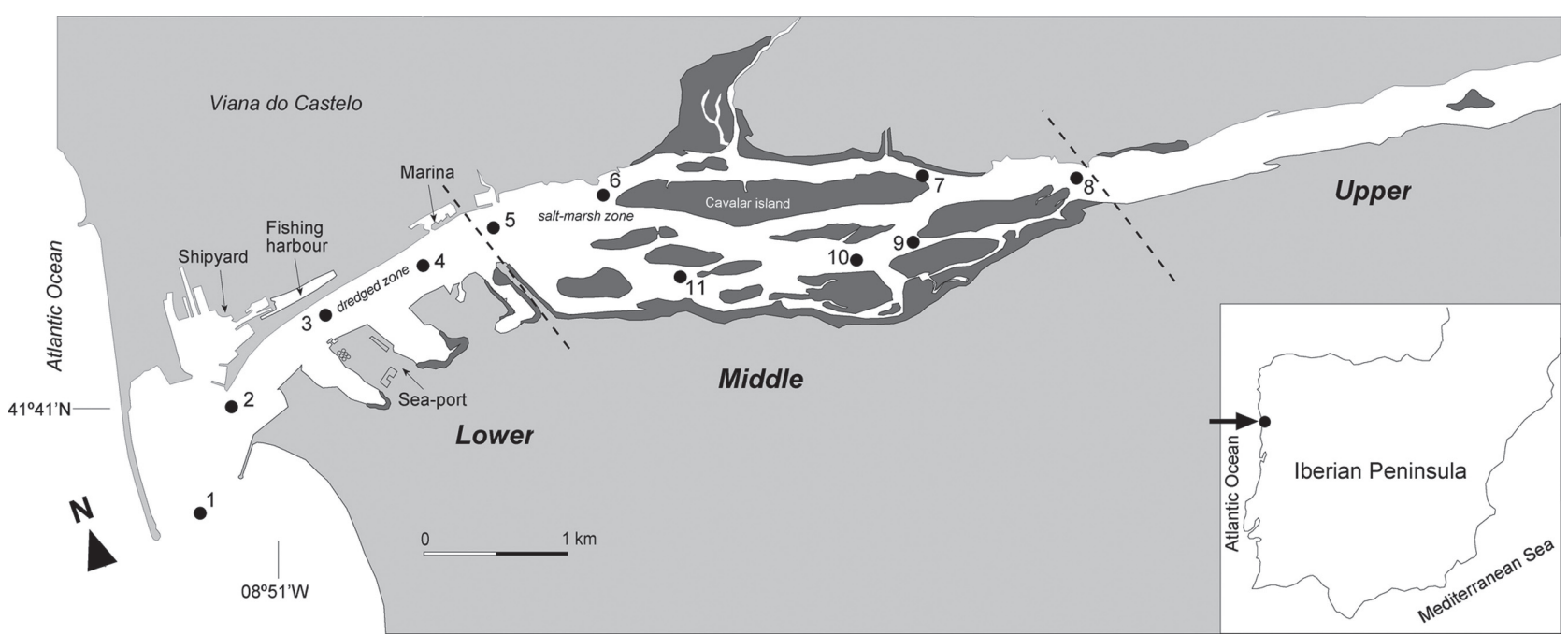

FIG. 1. - The Lima River estuary and location of the 11 sampling stations. Shaded area represents land (light grey) and sand islands and saltmarshes (dark grey). Dotted lines separate the three estuarine areas: lower, middle and upper estuary.

\section{Data collection}

Sardine larvae were collected during a major ichthyoplankton survey conducted in the Lima estuary between April 2002 and April 2004 (Ramos et al., 2006a). Sampling surveys were conducted fortnightly during spring tides in the Lima River estuary. Circular planktonic tows were performed with a conical net $1 \mathrm{~m}$ in diameter, $3 \mathrm{~m}$ long and with a $500 \mu \mathrm{m}$ mesh size in the subsurface water layer (1-2 m depth) at a constant velocity of ca. $1 \mathrm{~m}$ $\mathrm{s}^{-1}$ for five minutes. The volume of water sampled was recorded by a flowmeter (Hydro-Bios) attached to the net. At each sampling station, temperature, salinity, dissolved oxygen saturation, $\mathrm{pH}$ and turbidity of the subsurface water layer $(0.9$ and $2.1 \mathrm{~m}$ depth) were obtained by means of a YSI 6820 CTD. Precipitation and river flow data were obtained from the Portuguese Water Institute (http://snirh. $\mathrm{pt} /$ ). Upwelling index and sea surface temperature (SST) data between April 2002 and April 2004 relate to a station located at $41.5^{\circ} \mathrm{N}, 8.5^{\circ} \mathrm{W}$ and were retrieved from the Live Access to ERD Environmental Data (http://las.pfeg.noaa.gov/las6_5/servlets/constrain?var=1634). The Atlantic northwest coast of the Iberian Peninsula has a north-south orientation and, hence, northern winds produce offshore transport of surface coastal waters, which are replaced by deep upwelled water. Positive values of the index indicate upwelling events and consequently water transport offshore and potential indicators of offshore advection of larvae during the spawning season (Riveiro et al., 2004).

\section{Sample processing}

Ichthyoplankton samples were fixed in $4 \%$ buffered formalin $(\mathrm{pH}=8)$. After sorting, sardine larvae were preserved individually in $95 \%$ alcohol. Abundance was standardised as the number of sardine larvae $/ 100 \mathrm{~m}^{3}$. Total lengths (TL) of fish larvae were measured to the nearest $0.01 \mathrm{~mm}$ using an image analyser (Leica Microsystem DJ DC480, software LEICA QWin 32), and then corrected for shrinkage according to Theilacker (1980). Since sardine hatch with a total length of 3-4 mm (Ré, 1999), samples with a total length of less than 3 $\mathrm{mm}$ were considered to be pre-hatched individuals that had broken out of the egg capsule (disrupted capsules). Sardine larvae were assigned to one of the three development categories: pre-hatch (total length $<3 \mathrm{~mm}$ ), yolk-sack larvae (presence of yolk) and preflexion-flexion stages (without yolk and eyes completely pigmented). Age of the larvae was estimated through the conversion of body lengths into ages, using the larval length versus otolith growth increments linear equation (Ré, 1984). According to Russell (1976) and Ré (1999), the delay between fertilisation and hatching is 2.7 days and that between hatching and first-feeding is 4 days in an environment with average temperatures similar to those experienced in the Lima estuary $\left(15^{\circ} \mathrm{C}\right)$. A total of 6.7 days was therefore added to the estimated age. Individuals were aggregated into four age groups: $G_{1}\left(<8\right.$ days old), $G_{2}$ (between 8 and 14 days old), $G_{3}$ (between 15 and 21 days old) and $\mathrm{G}_{4}$ (>21 days old). Considering the pelagic larval 
duration of $S$. pilchardus to be of 40 days, $\mathrm{G}_{1}$ was considered as newly-hatched larvae.

\section{Data analyses}

Monthly data were averaged by season: spring (Sp) included March, April and May; summer (S) June, July and August; autumn (A) September, October and November; and winter (W) December, January and February. The temporal and spatial variations in sardine larvae abundance were assessed using a two way-ANOVA, with seasons and sampling stations as fixed factors (Sokal and Rohlf, 1995; Zar, 1996). Whenever necessary, raw data were log-transformed to meet the ANOVA assumptions of homogeneous variance and normally-distributed data. Homogeneity of variance was tested with Cochran's test. Whenever variance was still heterogeneous, conclusions from ANOVA results were only accepted for those cases in which significance levels were less than 0.01 . Furthermore, in the event of significance, an a posteriori Tukey HSD for unequal sample sizes was used to determine which means were significantly different at a 0.01 probability level (Spjotvoll and Stoline, 1973).

The environmental conditions associated with the spatial and temporal age patterns of sardines were investigated by means of canonical correspondence analysis (CCA), a multivariate method of direct gradient analysis (Ter Braak, 1986), using the CANOCO software (version 4.5, Microcomputer Power, Ithaca, NY). An environmental set of nine variables was used: water parameters (mean temperature, salinity, oxygen saturation, $\mathrm{pH}$ and turbidity of the subsurface water layer); monthly river flow and precipitation; upwelling index; and the temperature gradient between the sea surface temperature and the estuarine temperature. Samples were averaged into 3-month groups (i.e. seasons). Samples without sardine larvae were removed from the analysis. The option used for CCA was triplot scaling with a focus on interspecies distances, and species abundances were transformed (square root). Significance of the canonical model was given by a Monte Carlo test (Ter Braak and Smilaeur, 2002). Inter-set correlation coefficients were used to assess the importance of the environmental variables, and when inter-set $\geq|0.4|$ variables were considered to be biologically important (Rakocinski et al., 1996).

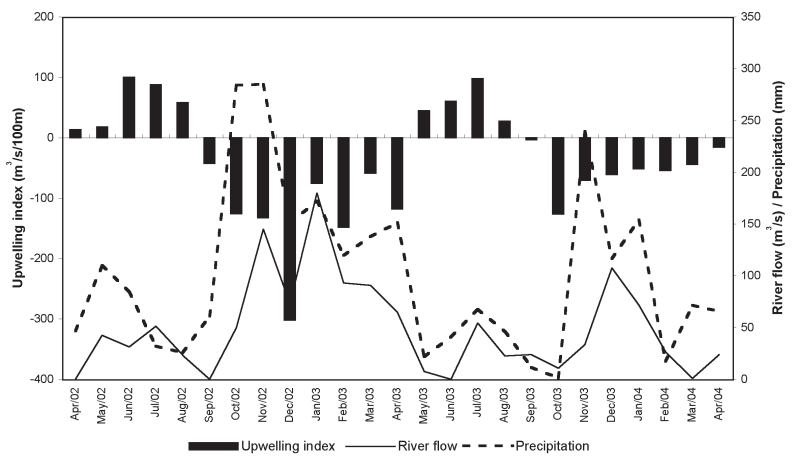

FIG. 2. - Monthly precipitation (mm), average monthly river flow $\left(\mathrm{m}^{3} \mathrm{~s}^{-1}\right)$ and upwelling index $\left(\mathrm{m}^{3} \mathrm{~s}^{-1} 100 \mathrm{~m}^{-1}\right)$ in the Lima estuary between April 2002 and April 2004. Positive values of the index indicate upwelling events.

\section{RESULTS}

\section{Environmental conditions}

During the study period, monthly precipitation varied between 1 and $285 \mathrm{~mm}$, and river flow ranged from 0 to $180 \mathrm{~m}^{3} \mathrm{~s}^{-1}$ (Fig. 2). Although precipitation and river flow fluctuated greatly throughout the study period, there was a general trend for an autumn-winter increase in both parameters. The wet period of the first study year was considerably longer and intense, with precipitation and river flow registering the highest values of the study. The monthly distribution of the upwelling index (Fig. 2) indicated that spring-summer upwelling events occurred in both years (positive values of index), although in the summer 2002 the intensity and duration of upwelling was demonstrably higher.

The physical and chemical characteristics of the subsurface water layer varied seasonally, and only a minor spatial variability between the lower and middle estuary was found (Fig. 3). Temperature ranged between 9.4 and $19.6^{\circ} \mathrm{C}$, with a mean of $14.8 \pm 1.9^{\circ} \mathrm{C}$, and exhibited the expected seasonal trend. It decreased during the winter months and increased during the spring-summer months. Nevertheless, in 2002 the summer temperature was lower than expected due to the above-mentioned strong upwelling, shifting the warmest period of the year to the autumn season. The Lima estuary was generally euhaline, with an average salinity above $30(30.6 \pm 6.5)$. The only exception was the wet winter of 2002-2003, when salinity decreased below 10 due to river flow increase. Water was in general well oxygenated, with an average oxygen saturation of $102.8 \pm 10.8 \%$, and values tended to 

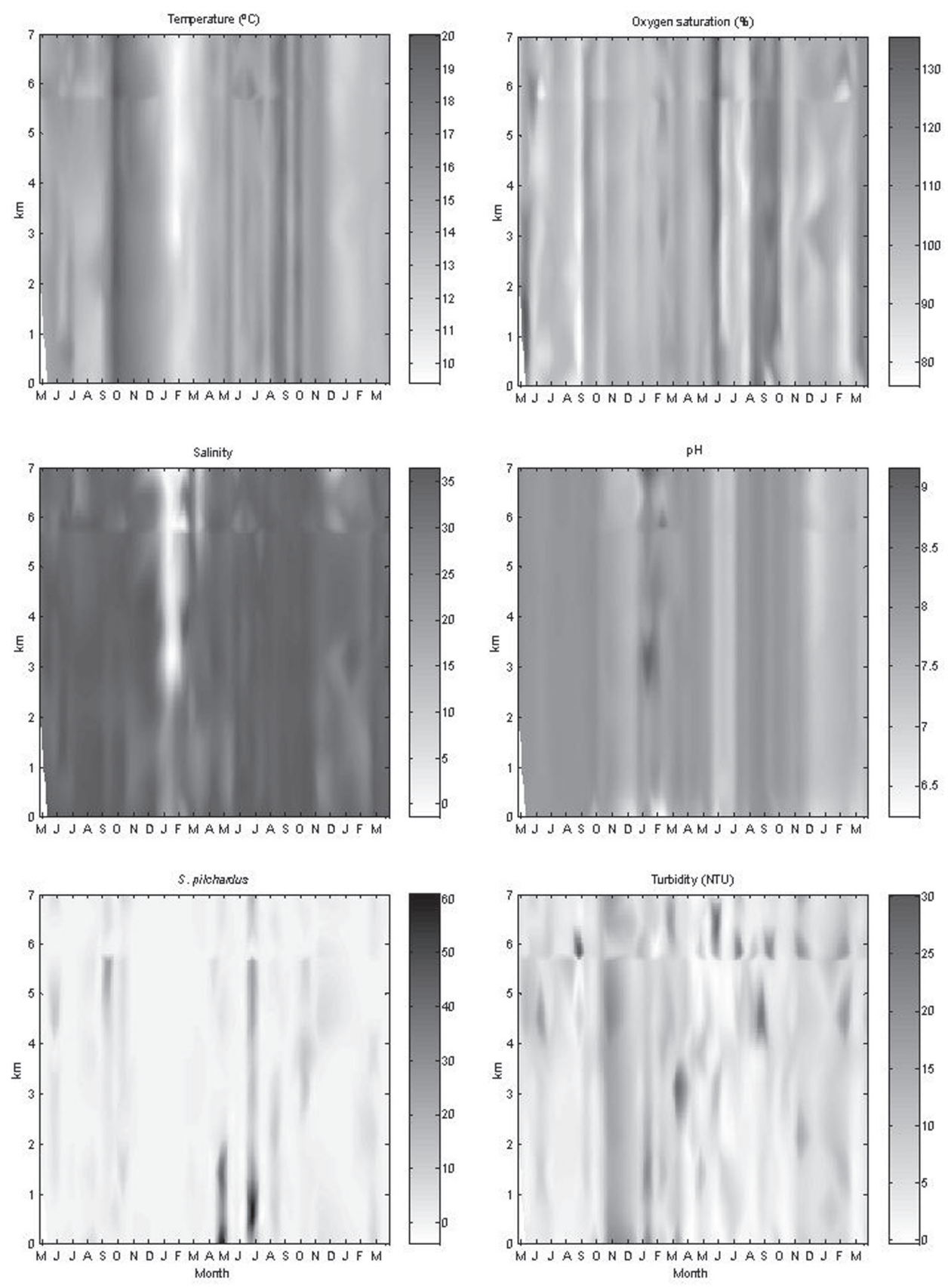

FIG. 3. - Interpolation plots of temperature, salinity, oxygen saturation, ph, turbidity of the subsurface water layer (0.9-1.2 $\mathrm{m}$ depth) and sardine larvae abundance (larvae $/ 100 \mathrm{~m}^{3}$ ) along the time (x-axis) and distance from the river mouth (y-axis) in the Lima estuary during April 2002 and April 2004. $\mathrm{km}$ - distance from the river mouth.

increase during the freshet periods (winter and early spring months). Conversely, $\mathrm{pH}$ (mean: 7.8 $\pm 0.4)$ tended to decrease during the freshet periods, which was particularly evident in the second sampling year. Mean seasonal turbidity was lower than 7 NTU (mean: $6.8 \pm 7.4$ NTU), except during the freshet period of the first study year, when the transparency of the water decreased due to increased runoff.

\section{Seasonal occurrence of sardine larvae}

During the study period, a total of 1064 sardine larvae were captured in the Lima estuary. Sardine larvae occurred in $31 \%$ of the total 489 plankton trawls. Abundance ranged from 0.5 to 60.8 larvae $/ 100 \mathrm{~m}^{3}$, with an average of $1.8 \pm 6.1$ larvae/ $/ 100 \mathrm{~m}^{3}$.

Three distinct development stages were observed: i) the most frequent and abundant stage (56\%) was 
TABLE 1. - Total length (mm), age (days), abundance (larvae/100 $\mathrm{m}^{3}$ ), frequency of occurrence (F.O.) and relative contribution to the total catch $(\%)$ of the sardine larvae caught in the Lima estuary from April 2002 until April 2004.

\begin{tabular}{|c|c|c|c|c|c|c|}
\hline Ontogenetic stages & & $\begin{array}{l}\text { Total length } \\
(\mathrm{mm})\end{array}$ & $\begin{array}{l}\text { Age } \\
\text { (days) }\end{array}$ & $\begin{array}{c}\text { Abundance } \\
(\text { larvae/100 m³ })\end{array}$ & F.O. & $\%$ \\
\hline Pre-hatch & Presence of egg capsule & $2.63 \pm 0.27$ & $2.20 \pm 0.48$ & $0.05 \pm 0.31$ & $4 \%$ & $3 \%$ \\
\hline Yolk-sack & $\begin{array}{l}\text { Yolk with an oil globule } \\
\text { Unpigmented eyes }\end{array}$ & $4.22 \pm 0.55$ & $5.01 \pm 0.97$ & $1.01 \pm 3.51$ & $22 \%$ & $56 \%$ \\
\hline Preflexion and flexion & $\begin{array}{l}\text { Yolk completely absorbed } \\
\text { Pigmented eyes }\end{array}$ & $7.18 \pm 2.71$ & $10.26 \pm 4.81$ & $0.73 \pm 3.78$ & $21 \%$ & $41 \%$ \\
\hline
\end{tabular}

that of yolk-sack larvae with unpigmented eyes and a total length of 3.0 to $6.1 \mathrm{~mm}$, corresponding to ages from 3 to 7 days (Table 1); ii) larvae in preflexion and flexion stages represented $41 \%$ of the total sardines collected, and included all individuals without yolk, with highly variable lengths, from 3.9 to $16.5 \mathrm{~mm}$ TL corresponding to ages from 4.4 to 26.7 days; and iii) just $3 \%$ of larvae were identified as pre-hatching stages, younger than 3 days (Table 1).

The occurrence of sardine larval stages in the Lima estuary varied significantly between seasons $(\mathrm{F}=6.99, P<0.001)$, with a distinct seasonality in each of the study years (Fig. 3). In 2002/2003, sardines were collected with a $25 \%$ frequency of occurrence, which increased to $38 \%$ during the second study year (2003/2004). Additionally, abundance peaked during autumn 2002 of the first year, and in the second year higher abundances were observed during the spring-summer period. Moreover, in $2002 / 2003$ the lowest abundance period was in the winter, but in 2003/2004 it was early spring, when only 3 and 5\%, respectively, of the planktonic trawls included sardine larvae.

Apart from the absence of significant differences between the lower and middle estuary $(\mathrm{F}=0.9$, $P>0.52$ ), or interaction between seasons and sampling stations $(\mathrm{F}=0.68, P>0.98)$, a slight decrease in sardine larval abundance upstream was found. Mean abundance was higher in the lower estuary $(2.9 \pm 8.7$ sardines $/ 100 \mathrm{~m}^{3}$ ), than in the middle estuarine area $\left(1.4 \pm 3.5\right.$ sardines $\left./ 100 \mathrm{~m}^{3}\right)($ Fig. 3).

\section{Age patterns}

The total length of the 1064 sardine larvae collected ranged from 1.8 to $16.5 \mathrm{~mm}$ TL, correspond-
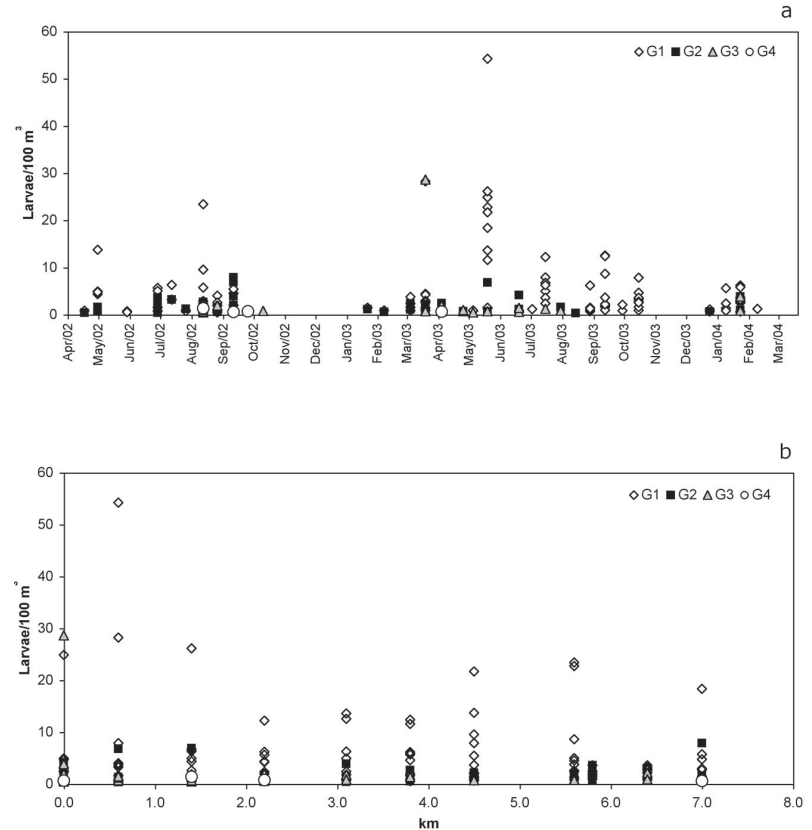

FIG. 4. - Monthly (a) and spatial (b) patterns of the four weekly age groups of sardine larvae collected in the Lima estuary between April 2002 and April 2004. G1, 1 week old; G2, 2 weeks old; G3, 3 weeks old; and G4, 4 weeks old.

ing to an age of 1-27 days. Sardines less than 8 days old occurred at a density of $1.5 \pm 4.9$ larvae $/ 100 \mathrm{~m}^{3}$. Abundance of those newly hatched larvae varied significantly between seasons $(\mathrm{F}=5.3, P<0.001)$, but not between sampling stations $(\mathrm{F}=0.8, P>0.62)$, and no interaction between seasons and stations was found $(\mathrm{F}=0.6, P>0.99)$. Among age groups, $\mathrm{G}_{1}$ was the most abundant and frequent, representing $80 \%$ of the positive collections (i.e. samples containing sardine larvae), and peaked during summer 2003, when abundance reached 54 larvae/100 $\mathrm{m}^{3}$ (Fig. 4). The 2-week old sardines represented $12 \%$ of the total and were observed in $35 \%$ of the 
positive collections, with a mean abundance of 0.2 \pm 0.9 larvae $/ 100 \mathrm{~m}^{3}$. Abundance of $\mathrm{G}_{2}$ group varied significantly between seasons $(\mathrm{F}=3.8, P<0.001)$, with a peak in autumn 2002. However, they were absent during spring 2004 (Fig. 4). Sampling station and the interaction between sampling station and season did not have significant effects on the abundance of $\mathrm{G}_{2}$ larvae $(\mathrm{F}=1.66$ and $0.85, P>0.09$ and $P>0.86$, respectively). Three week old larvae $\left(\mathrm{G}_{3}\right)$ were present in $18 \%$ of the positive collections, representing $7 \%$ of the total number of sardines, with a mean abundance of $0.1 \pm 1.4$ larvae/100 $\mathrm{m}^{3}$. As for the $\mathrm{G}_{1}$ and $\mathrm{G}_{2}$ age groups, seasons had a significant effect on the abundance of the $\mathrm{G}_{3}$ age group $(\mathrm{F}=2.99, P<0.001)$, unlike sampling stations $(\mathrm{F}=1.52, P>0.13)$, and interactions between season and station $(\mathrm{F}=0.87, P>0.76)$, which had no significant effect. $G_{3}$ sardines were only found during the higher abundance periods of each year (i.e. autumn 2002 and spring-summer 2003), but also during winter 2003/2004 (Fig. 3). Older sardines aged 22 or more days $\left(\mathrm{G}_{4}\right)$ were rare, representing $0.4 \%$ of the total sardines with a mean abundance of $0.01 \pm 0.1$ larvae $/ 100 \mathrm{~m}^{3}$. This age group was only observed during autumn 2002 and spring 2003 (Fig. 4), and did not show any significant seasonal $(\mathrm{F}=2.14, P>0.03)$ or spatial $(\mathrm{F}=0.64, P>0.78)$ variations.

\section{Responses to environmental forcing}

From the original set of nine environmental variables, $\mathrm{pH}$, turbidity, precipitation and temperature gradient were excluded due to the multicolinearity problems (inflation factor $>20$ ). The effect of the combined five variables on explained distribution of the CCA axes was significant according to the Monte Carlo permutation test $(P<0.05)$. The first CCA axis (eigenvalue $=0.12$ ), and the second CCA axis (eigenvalue $=0.07$ ) explained together $97 \%$ of the cumulative percentage variance of species-environment relation. Therefore the following two CCA axes $\left(\mathrm{CCA}_{3}\right.$ and $\left.\mathrm{CCA}_{4}\right)$ were not interpreted further. According to inter-set correlations, river flow, temperature, salinity and upwelling index were considered to be biologically significant (Table 2). $\mathrm{CCA}_{1}$ was positively correlated with upwelling index and negatively correlated with river flow. Temperature and salinity were negatively correlated with $\mathrm{CCA}_{2}$. The first canonical axis separated seasons with high river flow and low upwelling index such as autumn
TABLE 2. - Inter-set correlations of environmental variables with the first two CCA axes. * inter-set $\geq|0.4|$ corresponding to biologically important variables.

\begin{tabular}{lcc}
\hline Environmental variables & $\mathrm{CCA}_{1}$ & $\mathrm{CCA}_{2}$ \\
\hline River flow $\left(\mathrm{m}^{3} / \mathrm{s}^{1}\right)$ & $\mathbf{- 0 . 9}$ & -0.1 \\
Temperature $\left({ }^{\circ} \mathrm{C}\right)$ & -0.3 & $\mathbf{- 0 . 8}$ \\
Salinity & -0.1 & $\mathbf{- 0 . 7}$ \\
Oxygen saturation $(\%)$ & -0.2 & 0.2 \\
Upwelling index $\left(\mathrm{m}^{3} / \mathrm{s}^{1} 100 \mathrm{~m}\right)$ & $\mathbf{0 . 7}$ & 0.3 \\
\hline
\end{tabular}

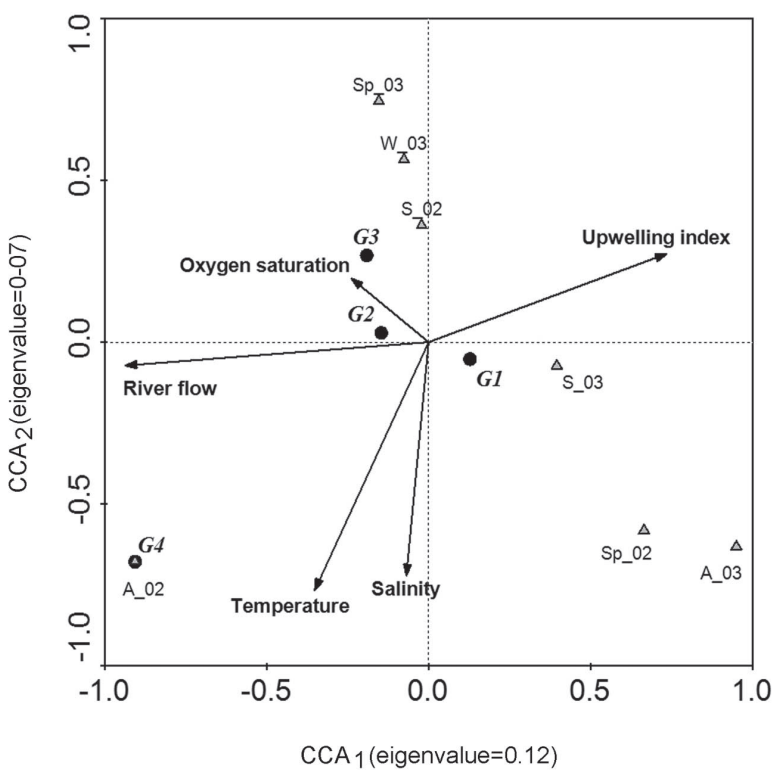

FIG. 5. - Sardine age groups and environmental variables in a triplot ordination diagram using the first two canonical correspondence axes. $G_{1}$, age group $1 ; G_{2}$, age group $2 ; G_{3}$, age group $3 ; G_{4}$, age group 4; NO, no sardine. Sp_02, spring 2002; S_02, summer 2002; A 02, autumn 2002; W_02, winter 2002/2003; Sp_03, spring 2003; S_03, summer 2003; A_03, autumn 2003; W 03, winter 2003/2004; Sp_04, spring 2004

2002 from seasons with reduced river flow such as spring 2002 and autumn 2003 (Fig. 5). The remaining seasons were separated along $\mathrm{CCA}_{2}$ by temperature and salinity since seasons whose mean temperature and salinity were below the $15^{\circ} \mathrm{C}$ and 33 , respectively, clustered in the positive part of $\mathrm{CCA}_{2}$ (Fig. 5). Sardine age groups were separated along the two first CCA axes. $G_{1}$ was correlated with upwelling events, since this age group peaked during the summer of 2003 (c.f. Fig. 4) and, therefore, clustered in the positive part of the $\mathrm{CCA}_{1}$ axis. The remaining age groups merged in the negative part of the $\mathrm{CCA}_{1}$ axis and were separated along $\mathrm{CCA}_{2} . \mathrm{G}_{4}$ clustered with the autumn of 2002 (Fig. 5), associated with high temperature and salinity values (Fig. 3). $G_{2}$ and $\mathrm{G}_{3}$ were associated with an increase in river flow and with the lower temperatures and salinities of summer 2002 and spring and winter 2003. 


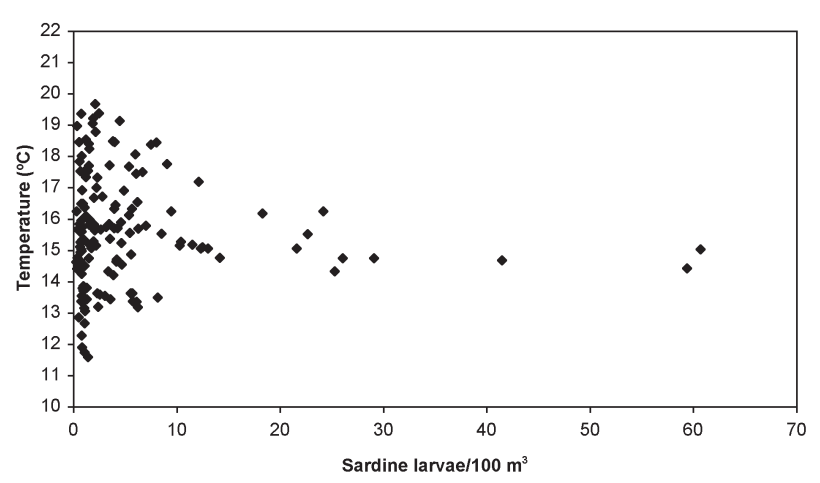

FIG. 6. - Sardine larval abundance versus temperature in the Lima estuary between April 2002 and April 2004.

\section{DISCUSSION}

According to a two-year-long study, S. pilchardus was the second most abundant species in the ichthyoplankton assemblage of the Lima estuary (Ramos et al., 2006a). This pattern has not been described before for Atlantic Iberian estuaries, where sardines have been considered a minor component of the estuarine ichthyoplankton assemblage, generally dominated by Engraulis encrasicolus, another clupeid species (Ribeiro, 1991; Ré, 1996; Ré, 1999; Faria et al., 2006; Marques et al., 2006). Although larval stages of sardines were considered rare in Iberian estuaries (Ré, 1999), in the present study, sardine larvae were frequently observed in the Lima estuary independently of the season. None of the sardine age groups revealed any specificity to a particular zone of the estuary owing to their rather good distribution along the initial $7 \mathrm{~km}$ of the Lima estuary. These findings contradict previous studies that reported sardine larvae as an occasional visitor restricted to the terminal zone of Iberian estuaries (Ré, 1999), providing new insight into the early life ecology of S. pilchardus along the Northern Iberian coast.

During the 25-month study period, sardines were frequently observed in the Lima estuary, exhibiting a clear seasonality that varied between years (Fig. $3)$. Two periods of low abundances emerged, in winter 2002 and spring 2004, followed by two peaks of high abundances, in autumn 2002 and springsummer 2003 (Fig. 3). According to Olivar et al. (2001; 2003), environmental variations can modify not only the distribution but also the abundance of sardine larvae, as was the case in the Lima estuary. Seasonal variations in the abundance of sardines followed temporal variations in water characteristics.
For example, the freshet period of winter 2002, when river flow exceeded $100 \mathrm{~m}^{3} \mathrm{~s}^{-1}$ and salinity decreased sharply (below the 25), coincided with the absence of sardine larvae (Fig. 3), and a decrease in larval fish assemblages (Ramos et al., 2006b). Thus, increased run-off limits the penetration of marine larvae into estuarine habitats. In winter 2003, river flow was lower and therefore average salinity did not decrease below 25 (Figs. 2 and 3). As a result, sardine larval abundance was higher than in the winter of 2002 (Fig. 3). The present data seem to indicate that whenever the salt intrusion was favourable (i.e. when the system was euhaline), larvae penetrated into the Lima estuary. Thus, the occurrence of sardine larval stages in the estuary was correlated with the salinity regime of the system, which was, in turn, controlled by river flow. Overall, salinity and river flow were identified as important regulatory environmental parameters of the occurrence of sardine larvae in the Lima estuary (Table 2).

A second period of sardine scarcity was observed during spring 2004. During this season, river flow registered the lowest values of the study period (Fig. 2). Considering that high recruitment levels should be expected for intensive river flow (Costa et al., 2007), the reduced abundance during spring 2004 could have been a consequence of the lower precipitation and river flow observed since the preceding winter (2003/2004). Therefore, one can hypothesise that the unusually high river-flow observed during winter 2002-2003 (Fig. 2), which preceded the spring-summer abundance peak, could have acted as a signal for the estuarine recruitment. Actually, physical and chemical stimuli of freshwater are usually required as a clue to drive migratory processes (Champalbert and Koutsikopoulos, 1995), leading to the strong positive impact of river discharges on coastal fisheries (Loneragan and Bunn, 1999; Chícharo et al., 2006a; Chícharo et al., 2006b; Meynecke et al., 2006) driven by the nutrient upload of river plumes.

The typical pelagic fish life-history strategy in areas of coastal upwelling favours spawning when the offshore transport is minimal and later feeding stages are able to exploit increases in productivity due to summer coastal upwelling (Cushing, 1982; Roy et al., 1989). This spawning strategy can serve as an adaptive mechanism to avoid offshore transport in upwelling areas and associated loss of eggs and larvae from the coastal nursery habitat (Parrish et al., 1981). The low abundances of sardine lar- 
vae observed during a typical summer upwelling, as was the case of summer 2002 (Fig. 2), supports the importance of such oceanographic events on the recruitment of small pelagic fishes such as sardines in the coastal zone. Upwelling intensity was shown to affect sardine recruitment off the NW Iberian Atlantic both positively and negatively (Dickson et al., 1988; Roy et al., 1995). During the summer of 2003, when the upwelling index did not approach the levels observed in 2002, sardine larvae reached the highest abundances (Fig. 4). Moreover, CCA revealed that upwelling index was an environmental control of sardine larvae abundance, namely that of the newly-hatched $\left(\mathrm{G}_{1}\right)$ larvae (Fig. 5).

Sardina pilchardus spawning activity is temperature-dependent, occurring mainly when surface water temperatures range from 14 to $16^{\circ} \mathrm{C}$ (Ré et al., 1990). In addition, Muiño et al. (2003) identified temperature as the major environmental factor responsible for temporal variations in sardine larvae abundance along the coast of northern Spain. In the Lima estuary, periods of maximum sardine abundance coincided with periods of water temperatures higher than $17^{\circ} \mathrm{C}$ (Fig. 3). These results are in agreement with the recent study by Bernal et al. (2007), who reported sardine spawning off the European Atlantic to occur at a temperature range of $12-17^{\circ} \mathrm{C}$. Similarly, peaks in abundance of sardine larvae inside the estuary (autumn 2002 and spring-summer 2003), were associated with increased temperatures (Fig. 6). Indeed, temperature was also indentified as an important environmental determinant of sardine larvae in the Lima estuary (Table 2 and Fig. 5). Thus, not only is temperature an important variable for coastal spawning, but it also has an indirect effect on the temporal patterns of sardine larvae distribution in the Lima estuarine habitat.

Sardine larvae were captured throughout the study period and were mainly composed of newlyhatched sardine larvae (i.e. sardines that were 1week old), indicating highly frequent spawning activity in this region. Since spawning occurs in the coastal area (Bernal et al., 2007), the temporal pattern of sardine larvae abundance in the estuary should reflect this activity. In fact, the maximum abundance values recorded (60 larvae $/ 100 \mathrm{~m}^{3}$ ), were similar to those reported for the coastal area during the spawning season (Ré et al., 1990; John et al., 1996; Santos et al., 2004). However, the maximum sardine abundance in the Lima estuary during autumn 2002 and spring, summer and autumn 2003 did not coincide with the adult spawning season described off northern Portugal, which occurs from November to April (Ré et al., 1990; Zwolinski et al., 2001; Stratoudakis et al., 2003; Bernal et al., 2007). This lack of temporal synchrony between previously reported spawning activity and occurrence of larvae inside the estuary may indicate a change in the spawning strategy of the northern Iberian sardines stock. Several scenarios can be hypothesised: (i) the high abundances of sardines during summer suggest that sardine populations could be extending their spawning season through late spring and summer; (ii) the typical coastal nursery ground is being extended throughout the study area, as observed further north in the Rias Baixas, NW Spain by Muino et al. (2003); and (iii) alternative estuarine spawning is taking place. These hypotheses require further investigation of the temporal abundance patterns of sardine eggs in the estuary as well as in the surrounding coastal waters. Moreover, the actual nursery role of the Lima estuary for $S$. pilchardus needs to be evaluated. According to Beck et al. (2001), a juvenile habitat should be considered a nursery ground whenever its contribution to the adult stock is high in comparison with other areas. The present study did not allow the assessment of the real contribution of the Lima estuary to the adult stocks of S. pilchardus. Although several authors defend the criteria of Beck et al. (2001) as fundamental for proving the nursery role of an habitat (Cattrijsse and Hampel, 2006), recruitment success depends not only on the survival and growth of juveniles spent in the nursery grounds, but also on the highly variable larval phase (Van der Veer, 1986; Beverton, 1995; Andersen et al., 2005). Thus, the unusual high abundance of sardine larvae within the Lima estuary is a crucial finding for the recruitment assess of $S$. pilchardus in the northern Iberian Atlantic. Due to the economic importance of sardines in European fisheries, the unusually high abundance and frequency of sardine larvae in an estuarine habitat is key information for the management and sustainability of this typically coastal species. Beare et al. (2004) emphasised that the use of estuaries can involve many difficult problems for fisheries managers monitoring these environments. Thus, assessing the effective role of the Lima estuary for this economically and socially important species is necessary, requiring future research to evaluate the contribution of the Lima estuary to the recruitment of the northern Iberian $S$. pilchardus stock. Though this study provides new 
insights into the early life ecology of sardines in the NW Iberian Atlantic, the use of the Lima estuary as a frequent spawning and nursery area for sardines requires further investigation.

\section{ACKNOWLEDGEMENTS}

A PhD fellowship to Sandra Ramos (SFRH/ BD/6968/2001) was awarded by the Portuguese Foundation for Science and Technology (FCT). The Viana do Castelo Port Administration is thanked for supplying the research vessel and crew used during the project. The authors thank all who participated in field surveys, and special thanks are due to Joana Silva Santos for helping in data collection and measuring the larvae. We are grateful to Kirsten GrorudColvert for her helpful comments on the manuscript. Additionally, this manuscript benefited from helpful suggestions from Dr. Thomas M. Grothues and from an anonymous reviewer who provided valuable comments for improving the manuscript.

\section{REFERENCES}

Andersen, B., J. Carli, P. Gronkjaer and J. Stottrup. - 2005. Feeding ecology and growth of age 0 year Platichthys flesus (L.) in a vegetated and a bare sand habitat in a nutrient rich fjord. J. Fish Biol., 66(2): 531-552.

Andreu, B. and J.S. Pinto. - 1957. Características histológicas y biométricas del ovario de sardina, S. pilchardus (Walb.), en la maduración, puesta y recuperción. Origen de los ovocitos. Inv. Pesq., VI: 3-38.

Beare, D., F. Burns, E. Jones, K. Peach, E. Portilla, T. Greig, E. McKenzie and D. Reid. - 2004. An increase in the abundance of anchovies and sardines in the north-western North Sea since 1995. Global Change Biol., 10: 1209-1213.

Beck, M.W., K.L.J. Heck, K.W. Able, D.L. Childers, D.B. Eggleston, B.M. Gillanders, B. Halpern, C.G. Hays, K. Hoshino, T.J. Minello, R.J. Orth, P.F. Sheridan, and M.P. Weinstein. - 2001. The identification, conservation, and management of estuarine and marine nurseries for fish and invertebrates. Bioscience, 51: 633-641.

Bernal, M., Y. Stratoudakis, S. Coombs, M.M. Angelico, A.L. de Lanzos, C. Porteiro, Y. Sagarminaga, M. Santos, A. Uriarte, E. Cunha, L. Valdes and D. Borchers. - 2007. Sardine spawning off the European Atlantic coast: Characterization of and spatiotemporal variability in spawning habitat. Prog. Oceanogr., 74: 210-227.

Beverton, R.J.H. - 1995. Spatial limitation of population size; the concentration hypothesis. Neth. J. Sea Res., 34: 1-6.

Blaber, S.J.M. - 2000. Tropical Estuarine Fishes: Ecology, Exploitation and Conservation. Blackwell Science, Oxford.

Blaxter, J.H.S. and J.R. Hunter. - 1982. The biology of the Clupeoid fishes. In: J.H.S. Blaxter, F.S. Russell and M. Yonge (eds.), Adv. Mar. Biol., pp. 3-194. Academic Press, London.

Bode, A., M.T. Alvarez-Ossorio, M.E. Cunha, S. Garrido, J.B. Peleteiro, C. Porteiro, L. Valdes and M. Varela. - 2007. Stable nitrogen isotope studies of the pelagic food web on the Atlantic shelf of the Iberian Peninsula. Prog. Oceanogr., 74: 115-131.

Borges, M., A. Santos, N. Crato, H. Mendes and B. Mota. - 2003. Sardine regime shifts off Portugal: a time series analysis of catches and wind conditions. Sci. Mar., 67: 235-244.
Cattrijsse, A. and Hampel, H. 2006a. European intertidal marshes: a review of their habitat functioning and value for aquatic organisms. Mar. Ecol. Progr. Ser., 324: 293-307.

Champalbert, G. and C. Koutsikopoulos. - 1995. Behavior, transport and recruitment of Bay of Biscay sole (Solea solea): laboratory and field studies. J. Mar. Biol. Ass. U. K., 75: 93-108.

Chícharo, L., M.A. Chícharo and R. Ben-Hamadou. - 2006a. Use of a hydrotechnical infrastructure (Alqueva Dam) to regulate planktonic assemblages in the Guadiana estuary: Basis for sustainable water and ecosystem services management. Est. Coast. Shelf Sci., 70: 3-18.

Chícharo, M., L. Chícharo, L. Valdes, E. Lopez-Jamar and P. Re. - 1998. Estimation of starvation and diet variation of the RNA/ DNA ratios in field-caught Sardina pilchardus larvae off the north of Spain. Mar. Ecol. Prog. Ser., 164: 273-283.

Chícharo, M.A., L. Chícharo and P. Morais. - 2006b. Inter-annual differences of ichthyofauna structure of the Guadiana estuary and adjacent coastal area (SE Portugal/SW Spain): Before and after Alqueva dam construction. Est. Coast. Shelf Sci., 70: 39-51.

Coombs, S., G. Boyra, L. Rueda, A. Uriarte, M. Santos, D. Conway and N. Halliday. - 2004. Buoyancy measurements and vertical distribution of eggs of sardine (Sardina pilchardus) and anchovy (Engraulis encrasicolus). Mar. Biol., 145: 959-970.

Costa, M.J., R. Vasconcelos, J.L. Costa and H.N. Cabral. - 2007. River flow influence on the fish community of the Tagus estuary (Portugal). Hydrobiologia, 587: 113-123.

Cunha, M.E. and I. Figueiredo. - 1988. Reproductive cycle of $S$. pilchardus in the central region off the Portuguese coast (1971/1987). ICES, C.M. 1988/H: 61: 1-30.

Cushing, D.H. - 1982. Climate and fisheries. Academic Press, London.

Dickson, R.R., P.M. Kelly, J.M. Colebrook, W.S. Wooster and D.H. Cushing. - 1988. North winds and production in the eastern North Atlantic. J. Plankton Res., 10: 151-169.

Elliott, M. and K.L. Hemingway. - 2002. Fishes in Estuaries. Blackwell, Oxford.

Faria, A., P. Morais and M.A. Chícharo. - 2006. Icthyoplankton Dynamics in the Guadiana Estuary and Adjacent Coastal Area, South-East Portugal. Est. Coast. Shelf Sci., 70: 85-97.

Figueiredo, I.M. and A.M.P. Santos. - 1989. Reproductive biology of Sardina pilchardus (Walb.): seasonal maturity evolution (1986 to 1988). ICES C.M. 1989/H: 40: 4.

García, A., C. Franco, A. Solá, M. Alonso and J.M. Rodríguez. - 1998. Distribution of sardine (S. pilchardus Walb.) egg and larval abundances off the Spanish North Atlantic coast (Galician and Cantabrian areas) in April 1987. ICES C.M.1988/H: 21: $1-8$.

Guisande, C., J. Cabanas, A. Vergara and I. Riveiro. - 2001. Effect of climate on recruitment success of Atlantic Iberian sardine Sardina pilchardus. Mar. Ecol. Prog. Ser., 223: 243-250.

John, H.-C., P. Ré and C. Zuelicke. - 1996. Sardine larvae in a spring-upwelling event off northern Portugal. Cienc. Biol. Ecol. Syst., 16: 193-198.

Lago de Lanzós, A., C. Franco and A. Solá. - 1988. Comparative study of the annual variation in the spawning intensity of sardine, S. pilchardus (Walb.), off Cantabria and NW Spain. ICES C.M. 1988/H: 73: 1-13.

Loneragan, N.R. and S.E. Bunn. - 1999. River flows and estuarine ecosystems: implications for coastal fisheries from a review and a case study of the Logan river, Southeast Queensland. Aust. J. Ecol., 24: 431-440.

Marques, S., U. Azeiteiro, J. Marques, J. Neto and M. Pardal. - 2006. Zooplankton and ichthyoplankton communities in a temperate estuary: spatial and temporal patterns. J. Plankton Res., 28: 297-312.

Meynecke, J.O., S.Y. Lee, N.C. Duke and J. Warnken. - 2006. Effect of rainfall as a component of climate change on estuarine fish production in Queensland, Australia. Est. Coast. Shelf Sci., 69: 491-504.

Muino, R., P. Carrera and M. Iglesias. - 2003. The characterization of sardine (Sardina pilchardus Walbaum) schools off the Spanish-Atlantic coast. ICES J. Mar. Sci., 60: 1361-1372.

Olivar, M.P., I. Catalán, M. Emelianov and M.L. Fernández de Puelles. - 2003. Early stages of Sardina pilchardus and environmental anomalies in the Northwestern Mediterranean. Est. Coast. Shelf Sci., 56: 609-619.

Olivar, M.P., J. Salat and I. Palomera. - 2001. Comparative study of 
spatial distribution patterns of the early stages of anchovy and pilchard in the NW Mediterranean Sea. Mar. Ecol Prog Ser., 217: 111-120.

Parrish, R.H., C.S. Nelson and A. Bakun. - 1981. Transport mechanisms and reproductive success of fishes in the California Current. Biol. Oceanogr., 1: 175-203.

Pestana, M.G. - 1989. Manancial ibérico-atlântico de sardinha (Sardina pilchardus, Walb.) Sua avaliação e medidas de gestão. Dissertação, Instituto Nacional de Investigação Científica, Lisboa.

Porteiro, C., P. Carrera and J. Miquel. - 1996. Analysis of Spanish acoustic surveys for sardine, 1991-1993: Abundance estimates and inter-annual variability. ICES J. Mar. Sci., 53: 429-433.

Powles, H., F. Auger and G.J. Fitzgerald. - 1984. Nearshore ichthyoplankton of a north temperate estuary. Can. J. Fish Aquat Sci., 41: 1653-1663.

Quintanilla, L. and N. Perez. - 2000. Spawning frequency of Sardina pilchardus (Walb.) off the Spanish North Atlantic coast in 1997. Fish. Res., 45: 73-79.

Rakocinski, C.F., J. Lyczkowski-Shultz and S.L. Richardson. - 1996. Ichthyoplankton assemblage structure in Mississippi sound as revealed by canonical correspondence analysis. Est. Coast. Shelf Sci., 43: 237-257.

Ramos, S., R.K. Cowen, P. Ré and A.A. Bordalo. - 2006a. Temporal and spatial distribution of larval fish assemblages in the Lima estuary (Portugal). Est. Coast. Shelf Sci., 66: 303-313.

Ramos, S., R.K. Cowen, C. Paris, P. Ré and A.A. Bordalo. - 2006b. Environmental forcing and larval fish assemblage dynamics in the Lima River estuary (northwest Portugal). J. Plankton Res., 28: 275-286.

Ré, P. - 1984. Evidence of daily and hourly growth in pilchard larvae based on otolith growth increments, Sardina pilchardus (Walbaum, 1792). Cybium, 8: 33-38.

Ré, P. - 1986. Ecologia da postura e da fase planctónica de Sardina pilchardus (Walbaum, 1792) na Região Central da Costa Portuguesa. Bol. Soc. Portuguesa Cienc. Nat., 23: 5-81.

Ré, P. - 1996. Anchovy spawning in the Mira estuary (southwestern Portugal). Sci. Mar., 60: 141-153.

Ré, P. - 1999. Ictioplâncton estuarino da Península Ibérica. Guia de identificação dos ovos e estados larvares planctónicos. Câmara Municipal de Cascais, Cascais.

Ré, P., R. Cabral e Silva, E. Cunha, A. Farinha, I. Meneses and T. Moita. - 1990. Sardine spawning off Portugal. Bol. Inst. Nac. Inv. Pescas., 15: 31-34.

Ribeiro, R. - 1991. Ictioplâncton do estuário do Mondego - Resultados. Revista de Biologia: Actas do I $I^{o}$ Encontro de Planctologistas Portugueses. 4: 233-244.

Riveiro, I., C. Guisande, I. Maneiro and A. Vergara. - 2004. Parental effects in the European sardine Sardina pilchardus. Mar Ecol. Prog. Ser. 274: 225-234.

Roy, C., C. Porteiro and J. Cabanas. - 1995. The optimal environmental window hypothesis in the ICES area: the example of the Iberian sardine. In: E. Hagen and A.J. Da Silva (eds.), Dynamics of Upwelling in the ICES area., pp. 57-65. International Council for the Exploration of the Sea, Copenhagen.

Roy, C.P., P. Cury, A. Fontana and H. Belvèze. - 1989. Stratégies spatio-temporelles de la reproduction des clupéidés des zones d'upwelling d'Afrique de l'Ouest. Aquat. Living Resour., 2: 21-29.

Russell, F.S. - 1976. The Eggs and Planktonic Stages of British Marine Fishes. Academic Press, London.

Santos, A., M. Borges and S. Groom. - 2001. Sardine and horse mackerel recruitment and upwelling off Portugal. ICES J. Mar. Sci., 58: 589-596.

Santos, A., A. Peliz, J. Dubert, P. Oliveira, M. Angelico and P. Ré. - 2004. Impact of a winter upwelling event on the distribution and transport of sardine (Sardina pilchardus) eggs and larvae off western Iberia: a retention mechanism. Cont. Shelf Res., 24: 149-165.

Sokal, R.R. and F.J. Rohlf. - 1995. Biometry. W.H. Freeman and Company, New York.

Solá, A., C. Franco, A. Lago de Lanzós and L. Motos. - 1992. Temporal evolution of Sardina pilchardus (Walb.) spawning on the N-NW coast of the Iberian Peninsula. Bol. Inst. Esp. Oceanogr., 8: $97-114$.

Spjotvoll, E. and M.R. Stoline. - 1973. An extension of the T-method of multiple comparison to include the cases with unequal sample sizes. J. Am. Stat. Assoc., 68: 976-978.

Stratoudakis, Y., M. Bernal, D. Borchers, M. Borges and F. Cardador. - 2003. Changes in the distribution of sardine eggs and larvae off Portugal, 1985-2000. Fish Oceanogr., 12: 49-60.

Stratoudakis, Y., S. Coombs, A.L. de Lanzos, N. Halliday, G. Costas, B. Caneco, C. Franco, D. Conway, M. Begona Santos, A. Silva and M. Bernal. - 2007. Sardine (Sardina pilchardus) spawning seasonality in European waters of the northeast Atlantic. Mar. Biol., 152: 201-212.

Ter Braak, C.J.F. - 1986. Canonical correspondence analysis: A new eigenvector technique for multivariate direct gradient analysis. Ecology, 67: 1167-1179.

Ter Braak, C.J.F. and P. Smilaeur. - 2002. CANOCO Reference manual and CanoDraw for Windows user's guide: software for Canonical Community Ordination (version 4.5). Microcomputer Power, Ithaca, NY, USA

Theilacker, G.H. - 1980. Changes in body measurements of larval northern anchovy, Engraulis mordax, and other fishes due to handling and preservation. Fish Bull., 78: 685-692.

Van der Veer, H. W. 1986. Immigration, settlement and density-dependent mortality of larval and early postlarval 0-group plaice Pleuronectes platessa population in the western Wadden Sea. Mar. Ecol. Progr. Ser. 29: 223-236.

Whitfield, A. - 1999. Ichthyofaunal assemblages in estuaries: A South African case study. Rev Fish Biol Fish., 9: 151-186.

Zar, J.H. - 1996. Biostatistical analysis. Prentice Hall. International Editions, New Jersey.

Zwolinski, J., Y. Stratoudakis and E. Soares. - 2001. Intra-annual variation in the batch fecundity of sardine off Portugal. J. Fish Biol., 58: 1633-1645.

Scient. ed: J.J. Govoni.

Received April 8, 2008. Accepted November 20, 2008.

Published online April 6, 2009 